\title{
The Amazonia Variant of Vibrio cholerae: Molecular Identification and Study of Virulence Genes
}

\author{
MAS Baptista, JRC Andrade*, ACP Vicente**, CA Salles***, A Coelho/ ${ }^{+}$
}

\begin{abstract}
Departamento de Genética- I. Biologia, Universidade Federal do Rio de Janeiro, Ilha do Fundão, Cx Postal 68011, 21944-970 Rio de Janeiro, RJ, Brasil *Serviço de Microbiologia e Imunologia, Universidade do Estado do Rio de Janeiro **Departamento de Genética, Instituto Oswaldo Cruz ***Departamento de Bioquímica e Biologia Molecular, Instituto Oswaldo Cruz, Rio de Janeiro, RJ, Brasil
\end{abstract}

The pathogenic OI Amazonia variant of Vibrio cholerae has been shown previously to have a cytotoxin acting on cultured Vero and Y-1 cells, and to lack important virulence factors such as the cholera toxin (Coelho et al. 1995a). This study extends the molecular analysis of the Amazonia strains, detecting the presence of the tox $R$ gene, with a very similar sequence to that of the El Tor and classical biotypes. The outer membrane proteins are analyzed, detecting a variation among the group of Amazonia strains, with three different patterns found. As a by-product of this work a polymerase chain reaction fragment was sequenced, reading part of the sequence of the Lon protease of the Amazonia strains. This gene was not previously described in V. cholerae, but its sequence is present in the TIGR database specific for this species.

Key words: Vibrio cholerae - Amazonia - toxR - outer membrane proteins - protease - Lon

The Amazonia variant of Vibrio cholerae was isolated from a group of clinical O1 isolates obtained from the northwest of Brazil in 1991-1992 (Coelho et al. 1995a). The Latin American epidemic was caused by a strain of the El Tor biotype. It spread out from the Pacific coast of Latin America inwards, mainly following the Amazon river basin, reaching the northeast of Brazil and coming down up to the Rio de Janeiro region. A collection of strains from the beginning of the epidemic in Brazil was analyzed by the random amplified polymorphic DNA (RAPD) discriminative technique (Coelho et al. 1995b), and a surprising result was obtained. There was a group of strains with a different fingerprint pattern from the epidemic El Tor strains. All of these strains presented the same pattern, showing that they represented a distinct group.

These 14 strains were analyzed by various techniques. Biochemically they are undistinguishable from other $V$. cholerae strains. All of these strains were Ogawa, in contrast to the majority of strains collected at this time that were Inaba. However

This work was supported by a combination of grants from the following institutions: Pronex (CNPq), CAPES, CNPq, Universidade Federal do Rio de Janeiro, Universidade do Estado do Rio de Janeiro, FUJB (Brazil), PAPES (Fiocruz).

${ }^{+}$Corresponding author. Fax:+55-21-280-8043. E-mail: coelho@acd.ufrj.br

Received 15 June 1998

Accepted 30 July 1998 other El Tor strains from the same time and area were also Ogawa. The isozyme method (Salles \& Momen 1991) was used on these strains, and they were classified into a new group. The same thing happened with ribotypes (Popovic et al. 1993), and they formed a new group.

The Amazonia strains were tested for the presence of the $c t x$ gene (Kaper \& Levine 1981, Salles et al. 1993, Kaper et al. 1994), encoding the cholera toxin, and the result was negative. The presence of other virulence genes was tested by polymerase chain reaction (PCR), and neither the ST (thermo-stable toxin) (Ogawa et al. 1990, Vicente et al. 1997a) nor the zot (zonula occludens) toxin (Baudry et al. 1992) were found. The tcpA gene, coding for the colonization pilus (Taylor et al. 1987, Rhine \& Taylor 1994, Manning 1997, Vicente et al. 1997b), was not found by PCR or Southern hybridization.

When tested on rabbit ligated ileal loop, the strain did not produce an accumulation of liquid, but did show a destruction of the intestinal ephitelium, a heavy mucus production, with a large number of erythrocytes and epithelial cells embedded in it. In in vitro studies on cultured Vero cells, the production of a cytotoxin was detected, leading to morphological alterations of the cells, their detachment from the plastic and death.

In this paper the analysis of virulence genes of the Amazonia strain is extended, mainly with the study of the regulatory gene tox $\mathrm{R}$ (Peterson \& Mekalanos 1988, DiRita \& Mekalanos 1991, DiRita et al. 1991). tox $\mathrm{R}$ is considered a main regulatory gene, responsible for the recognition of en- 
vironmental stimuli for expression of a number of genes collectively denominated the ToxR virulence regulon (Skorupski \& Taylor 1997, Champion et al. 1997). The major outer membrane protein of $V$. cholerae, $\mathrm{OmpU}$, is directly regulated by the ToxR protein (Miller \& Mekalanos 1988, Sperandio et al. 1995, Chakrabarti et al. 1996, Crawford et al. 1998). The outer membrane proteins of the Amazonia strains are also analyzed here.

\section{MATERIALS AND METHODS}

Bacterial strains - Fourteen V. cholerae Amazonia strains were previously described (Coelho et al. 1995a). A further group of six strains was obtained from Cholera Reference Center (Fiocruz, Brazil). A streptomycin resistant derivative of one of the original strains, 4010 was used for all the experiments described in this paper. Control classical and El Tor strains were O395 and E7946 respectively.

DNA preparation, $P C R$ reaction conditions and product analysis - Bacteria were grown overnight in alkaline peptone water $(1 \mathrm{ml})$ and DNA was extracted (Silhavy et al. 1984). The program used for PCR consisted of 35 cycles, at $94^{\circ} \mathrm{C}$ for $1 \mathrm{~min}, 55^{\circ} \mathrm{C}$ for $1 \mathrm{~min} 30 \mathrm{sec}$ and $72^{\circ} \mathrm{C}$ for $1 \mathrm{~min} 30 \mathrm{sec}$. The reactions included $1 \mathrm{ml}$ of each primer $(500 \mathrm{ng} / \mathrm{ml})$, 100ng of DNA, dNTP's $50 \mathrm{mM}$ each, $5 \mathrm{ml}$ reaction buffer (1.5mM MgCl final concentration), $0.5 \mathrm{ml}$ Taq polymerase (2.5U) (Pharmacia) and distilled water to a total volume of $50 \mathrm{ml}$. An MJ Research thermocycler (Watertown, Mass.) was used for the temperature cycling. Primers used for the toxR fragment of 560bp were: OL.1: 5' TCGGATTAGGA CACAACTC and OL.2: 5' CTGCGAGGGGAA GTAAGAC. DNA was analyzed on $1.4 \%$ agarose gels in TBE 1X, prepared according to Sambrook et al. (1989), and running at 100 Volts for approximately $2 \mathrm{hr} 30 \mathrm{~min}$, until the bromophenolblue reached the end of the gel.

Southern transfer and hybridization - Southern transfers to nitrocellulose were done according to Sambrook et al. 1989. The hybridization solution was $50 \%$ formamide, 6 X SSC, $0.7 \%$ SDS. DNA (200ng) was labeled with the Random Primer kit (Life Technologies) employing aP32 dCTP.

Plasmid preparations, DNA restriction and ligation - Plasmid preparations employed Qiagen P100 columns according to instructions of the manufacturers. Restrictions were done as described by the enzyme manufacturers (Life Technologies). A five to one proportion of insert fragment was used in the cloning experiments. Electroporation was done into the Escherichia coli strain DH5a.

Outer membrane proteins preparation and protein analysis on SDS-polyacrylamide gels - Outer membrane proteins were prepared from $1 \mathrm{ml}$ of cells.
Bacteria were spun down and treated for $10 \mathrm{~min}$ with $0.06 \mathrm{M}$ Tris $\mathrm{HCl}(\mathrm{pH} 8.0) / 0.2 \mathrm{M}$ sucrose, $0.2 \mathrm{mM}$ EDTA and $0.04 \mathrm{mg} / \mathrm{ml} \mathrm{lysozyme} \mathrm{(total} \mathrm{volume} 500$ $\mathrm{ml}) .10 \mathrm{ml}$ of $1 \mathrm{mg} / \mathrm{ml}$ DNAse were added, and then $500 \mathrm{ml}$ of Triton extraction buffer [ $2 \%$ Triton X-100,

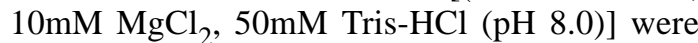
added. Outer membrane fragments were spun down and washed with water for three times. Proteins were resuspended in SDS-PAGE sample buffer, boiled for $5 \mathrm{~min}$, and loaded on 12\% SDS-polyacrylamide gels with 5\% stacking gels. Electrophoresis was carried out at constant current $(35 \mathrm{~mA})$, and the gels were stained with $0.25 \%$ Coomassie blue, and destained with methanol/acetic acid.

DNA sequencing and analysis - DNA sequencing was done employing the Thermo-sequenase kit (Amersham) and aP33 labeled dideoxy nucleotides. Plasmid DNA or PCR amplicons were sequenced. Specific bands on agarose gels were cut, and the DNA purified with the Sephaglass kit (Pharmacia). $300 \mathrm{ng}$ of DNA and $0.5 \mathrm{ml}$ of the ddNTPs were used for sequencing. Standard $60 \mathrm{~cm} 6 \%$ polyacrylamidebisacrylamide gels were used, with a glycerol tolerant buffer provided with the kit. The gels were fixed and dried and Hyperfilm was exposed for the visualization of the bands.

Databank searches with the sequences were made against the specific $V$. cholerae TIGR database at the Institute for Genomic Research (www.ncbi.nlm.gov/cgi-bin/BLAST/nph-tigrbl) and against the non-redundant combined database through the Blast Search (www.ncbi.nlm.nih.gov/ cgi-bin/BLAST/nph-newblast?Jform=0). Individual sequences were retrieved from the Genbank (www2.ncbi.nlm.nih.gov/genbank/query_ form.html).

\section{RESULTS}

Presence of the toxR gene - Primers OL.1 and OL.2 were used in a test to check whether the tox gene was present. Fig. 1A shows the presence of a strong band with an expected size of $560 \mathrm{bp}$, for various Amazonia strains. The gel was transferred and hybridized to a probe prepared from a classical strain, by amplification with the same primers. Hybridization was positive, as shown in Fig. 1B.

Cloning of a fragment of the toxR gene - The $560 \mathrm{bp}$ PCR fragment of the Amazonia tox $\mathrm{R}$ was cloned into the pBluescript SK vector, using SmaI, and producing the plasmid pMB560R. This fragment was then transferred to a second plasmid, pCVD442 (Donnenberg \& Kaper 1991), a suicide plasmid that does not replicate in V. cholerae. XbaI and SalI were used in the second cloning, and the plasmids obtained were denominated pCVD560R (Fig. 2). A restriction analysis of two such clones (Fig. 3A), and hybridization to the Amazonia tox R 
A

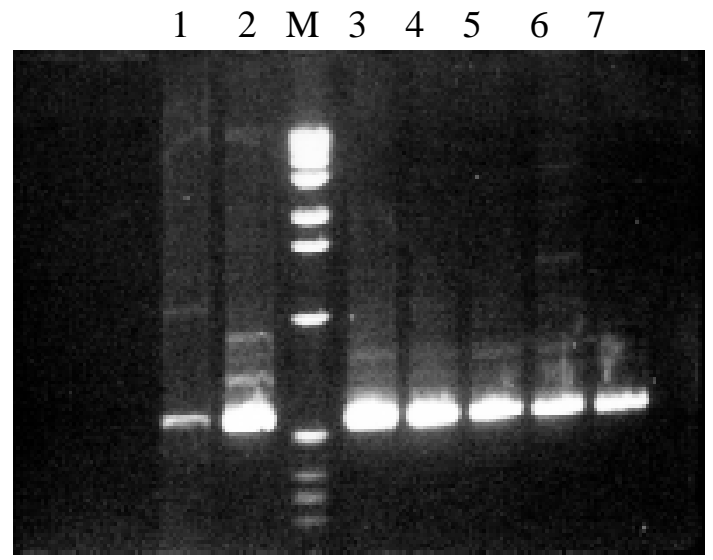

B

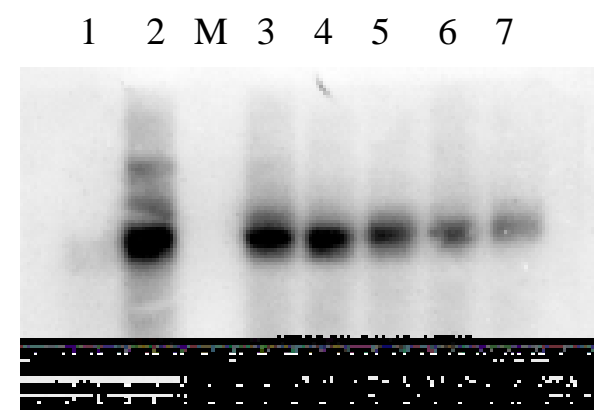

Fig. 1A: toxR PCR amplification from Amazonia strains. tox $\mathrm{R}$ primers were OL.1 and OL.2, which delimit a fragment of 560bp. Lanes 1 and 2 contain products from the Escherichia coli DH5a (negative control) and the classical strain O395, respectively. Lanes 3 through 7, PCR products from the Amazonia strains. 3, 4010; 4, 3729; 5, 3506; 6, 3439 and 7, L-34. M indicates the size marker, $1 \mathrm{~kb}$ ladder (Life Technologies). Fig. 1B: Southern hybridization of the gel on A with the 560bp toxR fragment from the $\mathrm{O} 395$ classical strain.

(Fig. 3B) were done, in a structural analysis of the clones.

Partial sequencing of the toxR gene - The tox $\mathrm{R}$ Amazonia 560bp fragment was sequenced, using both a universal primer for the pMB560R or internal tox $\mathrm{R}$ primers. A high similarity of the sequence (98.6\%) was found to that of the classical biotypes (Fig. 4A). A translation of this sequence shows a 98.4\% identity to the classical and El Tor ToxR protein (Fig. 4B). An arginine (R) for threonine $125(\mathrm{~T})$ substitution in particular could cause a difference in the secondary structure of the protein.

A
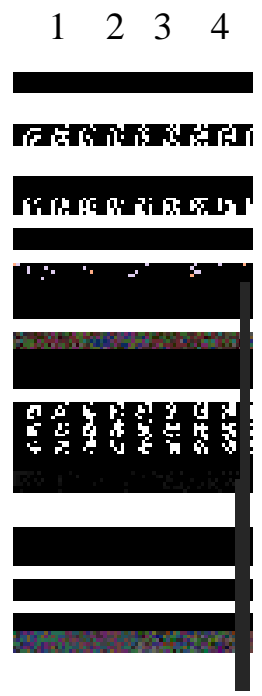

Fig. 3A: PstI restriction analysis of pCVD442 and two different pCVD560R clones. Lane 1, $1 \mathrm{~kb}$ ladder (Life Technologies); lane 2, pCVD442; lane 3, pCVD560R cl.1; lane 4, pCVD560R cl.2. Fig. 3B: hybridization of the gel on A to a 4010 Amazonia 560bp tox R probe.

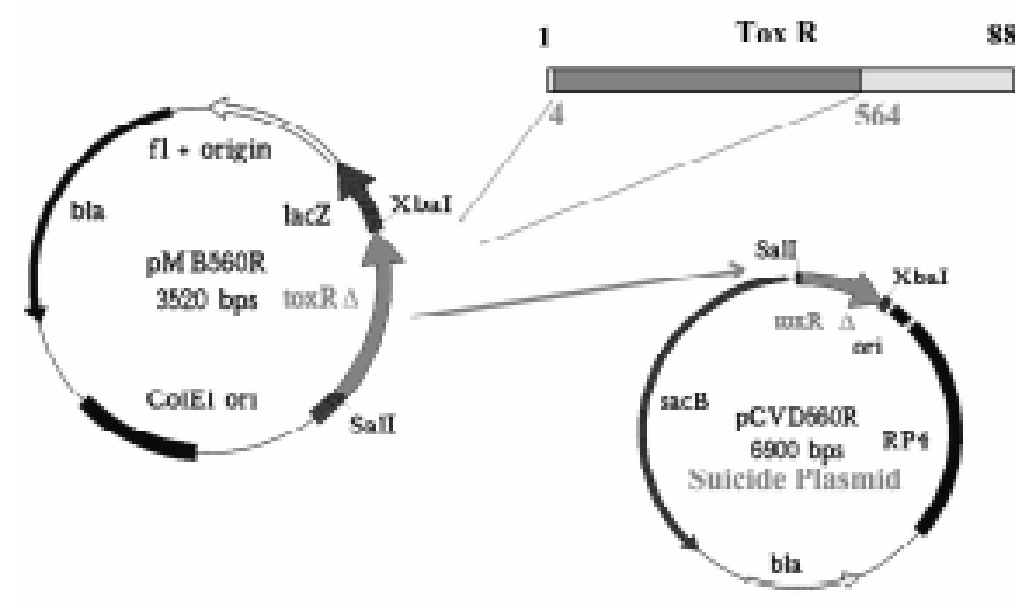

Fig. 2: cloning of the 560bp PCR fragment of the Amazonia strain 4010Sm ${ }^{\mathrm{r}}$ into the SmaI site of pBluescript SK, producing plasmid pMB560R and further cloning, with $\mathrm{XbaI}$ and SalI, into pCVD442, to yield plasmids pCVD560R. 
A

Fig. 4A: DNA sequence of the toxR fragment from the Amazonia strain 4010 compared to the sequence of the classical 569B strain. Numbers correspond to the number of nucleotides. * are used to mark the same nucleotide as in the previous line. Fig. 4B: aminoacid comparison between a translation of the DNA sequence of the Amazonia strain 4010, compared to the sequence of the ToxR protein of classical strain 569B and El Tor strain E7946. * are used to mark the same aminoacid as in the previous line. 
The major outer membrane proteins of Amazonia strains - The outer membrane proteins of the Amazonia strains were analyzed on polyacrylamide gels (Fig. 5). Three types of patterns were obtained. Some strains present one major protein with a size of $38 \mathrm{kDa}$, as the $38 \mathrm{kDa}$ OmpU protein of the El Tor and classical strains. Other strains present one smaller protein of $35 \mathrm{kDa}$. A

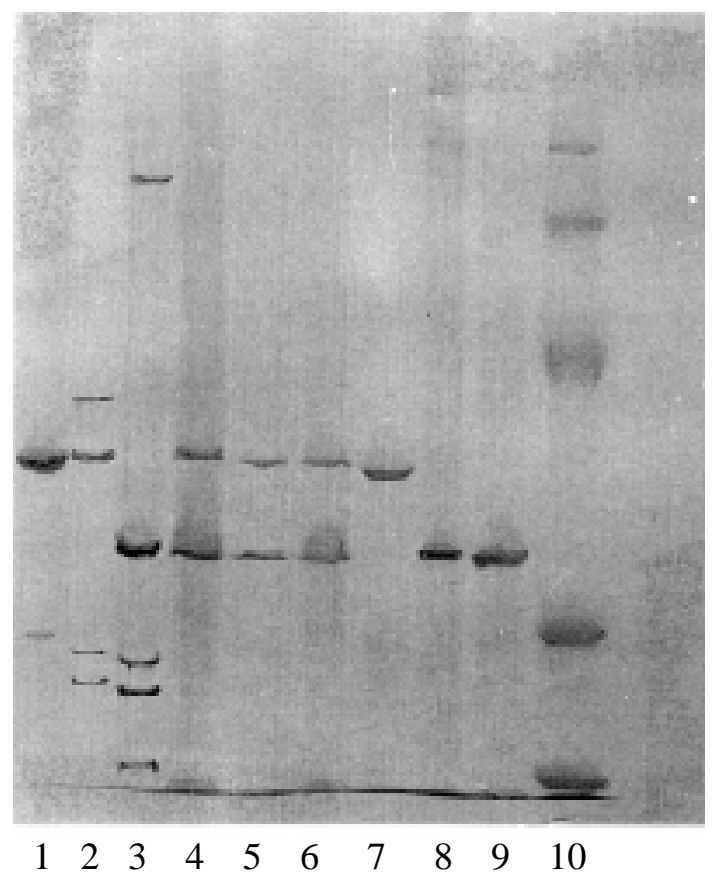

Fig. 5: SDS- polyacrylamide gel electrophoresis of outer membrane proteins. Lane 1: classical strain O395; 2-6, Amazonia variant strains $(2, \mathrm{~L}-34 ; 3,3218 ; 4,3439 ; 5,4010 ; 6,3506) ; 7$, El Tor (607); 8 and 9, Amazonia variant strains (8, 3501; 9, 4132); 10, protein molecular weight markers. third group presents both of these proteins. Different media were used for growth, to check whether this major proteins would vary according to growth conditions (data not shown), but it seems that the pattern is strain determined.

Presence of the lon gene - In the process of looking for virulence related genes, we obtained a spurious 800bp PCR amplicon that was partially sequenced. This sequence corresponds to the Lon protease of various bacteria. This is one of the main proteases, responsible for the degradation of misfolded proteins (Gottesman 1996). In Fig. 6 we compare the sequence of the Amazonia strain putative Lon protein to a sequence found in the TIGR databank for V. cholerae and to the other bacteria and archae.

\section{DISCUSSION}

The pathogenic O1 Amazonia Vibrio cholerae may be considered a new human pathogen. It was discovered with the use of discriminative molecular techniques (Coelho et al. 1995b, 1997). This strain belongs to the same species as the epidemic strains but seems to cause diarrhea by a different mechanism. The lack of the cholera toxin, and the presence of a cytotoxin leading to intestinal tissue damage in rabbits strongly suggest a different route for the disease.

The tox $\mathrm{R}$ gene was found in the Amazonia strains, and its sequence is highly homologous to that of the El Tor and classical biotypes. A toxR homologous gene has been described in Vibrio parahaemolyticus, Vibrio fischeri and a Photobacterium sp., with much lower DNA homology values, all below $70 \%$.

The presence of the regulatory gene tox $\mathrm{R}$, in the absence of various genes that it normally regulates, leads to the question of its further role. One possibility is the regulation of the outer membrane

\section{E. Coli \\ V. cholerae \\ V.chol. Amazonia}

Hae. inf.

Arch. fulgidus

Meth. thermo.

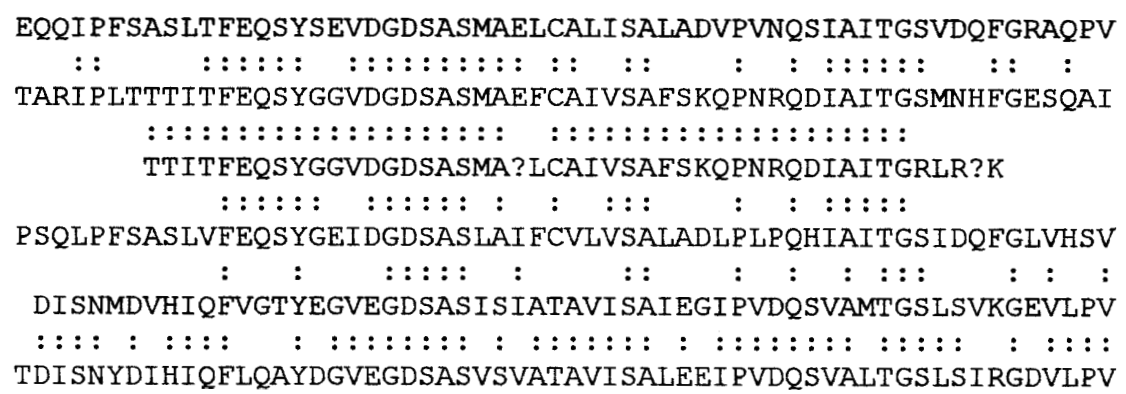

Fig. 6: aminoacid sequence comparison of the Amazonia putative Lon protease and the corresponding protein in other bacteria and archae. Bacteria: Escherichia coli, Vibrio cholerae, Haemophilus influenzae. Archae: Archaeoglobus fulgidus and Methanobacterium thermoauxotrophicum. 
proteins. It is known that tox $\mathrm{R}$ directly regulates the OmpU protein, which has been proposed as an adhesin with a role in virulence (Sperandio et al. 1995, 1996). The Amazonia strain, as in the case of El Tor and classical strains, presents major outer membrane proteins, which could have functional homologies to OmpU. Further developments in this work will include studies on the presence of other regulatory genes such as genes of the tcp cluster, like the $t c p \mathrm{P}$ and $t c p \mathrm{H}$ (Carroll et al. 1997, Manning 1997, Häse \& Mekalanos 1998) and other putative virulence genes (Karaolis et al. 1998, Tacket et al. 1998). It will also aim at the construction of tox $\mathrm{R}$ mutants to evaluate the role of this gene in the pathogenicity of the Amazonia strain, including an analysis of its adhesion to cells, cytotoxicity, and behavior in rabbit ileal loops. These comparative studies may shed light not only on the virulence mechanisms involved in the Amazonia strain but also on $V$. cholerae itself.

\section{ACKNOWLEDGMENTS}

To the Cholera Reference Center (Fiocruz) that provided a second group of six strains that we typed as belonging to the Amazonia group

\section{REFERENCES}

Baudry B, Fasano A, Ketley J, Kaper JB 1992. Cloning of a gene (zot) encoding a new toxin produced by Vibrio cholerae. Infect Immun 60: 428-434.

Carroll PA, Tashima KT, Rogers MB, DiRita VJ, Calderwood SB 1997. Phase variation in tcpH modulates expression of the ToxR regulon in Vibrio cholerae. Mol Microbiol 25: 1009-1011.

Chakrabarti SR, Chaudhuri K, Sem K, Das J 1996. Porins of Vibrio cholerae: purification and characterization of OmpU. J Bacteriol 178: 524-530.

Champion GA, Neely MN, Brennan MA, DiRita VJ 1997. A branch in the ToxR regulatory cascade of Vibrio cholerae revealed by characterization of tox $\mathrm{T}$ mutant strains. Mol Microbiol 23: 323-331.

Coelho A, Andrade JRC, Baptista MAS, Vicente ACP, Ferraz LR, Salles CA 1997. Genomic fingerprints of Vibrio cholerae using arbitrary primer PCR are useful epidemiological tools, p. 203-211. In GT Keusch, M Kawakami (eds), Cytokines, Cholera and the Gut, IOS Press, Netherlands.

Coelho A, Andrade JRC, Vicente ACP, Salles CA 1995a. A new variant of Vibrio cholerae $\mathrm{O} 1$ from clinical isolates in Amazonia. J Clin Microbiol 33: 114118.

Coelho A, Vicente ACP, Baptista MAS, Momen H, dos Santos FRW, Salles CA 1995b. The distinction of pathogenic Vibrio cholerae groups using arbitrarily primed PCR fingerprints. Res Microbiol 146: 671683.

Crawford JA, Kaper JB, DiRita VJ 1998. Analysis of ToxR-dependent transcription activation of ompU, the gene encoding a major envelope protein in Vibrio cholerae. Mol Microbiol In press.
DiRita VJ, Mekalanos JJ 1991. Periplasmic interaction between two membrane regulatory proteins, ToxR and ToxS, results in signal transduction and transcriptional activation. Cell 64: 29-37.

DiRita V, Parsot C, Jander G, Mekalanos JJ 1991. Regulatory cascade controls virulence in Vibrio cholerae. Proc Natl Acad Sci USA 88: 5403-5407.

Donnenberg MS, Kaper JB 1991. Construction of an eae deletion mutant of enteropathogenic Escherichia coli by using a positive- selection suicide vector. Infect Immun 59: 4310-4317.

Gottesman S 1996. Proteases and their targets in Escherichia coli. Ann Rev Genet 30: 465-506.

Häse CC, Mekalanos JJ 1998. TcpP is a positive regulator of virulence gene expression in Vibrio cholerae. Proc Natl Acad Sci USA 95: 730-734.

Kaper JB, Fasano A, Trucksis M 1994. Toxins of Vibrio cholerae, p. 145-176. In IK Wachsmuth, PA Blake, $\varnothing$ Olsvik (eds), Vibrio cholerae and cholera: molecular to global perspectives, ASM Press, Washington.

Kaper JB, Levine MM 1981. Cloned cholera enterotoxin genes in study and prevention of cholera. Lancet ii: 1162-1163.

Karaolis DK, Johnson JA, Bailey CC, Boedeker EC, Kaper JB, Reeves PR 1998. A Vibrio cholerae pathogenicity island associated with epidemic and pandemic strains. Proc Natl Acad Sci USA 95: 31343139.

Manning PA 1997. The tcp gene cluster of Vibrio cholerae. Gene 192: 63-70.

Miller VL, Mekalanos JJ 1988. A novel suicide vector and its use in construction on insertion mutations: osmoregulation of outer membrane proteins and virulence determinants in Vibrio cholerae requires tox $\mathrm{R}$. J Bacteriol 170: 2575-2583.

Ogawa A, Kato J-I, Watanabe H, Nair BG, Takeda T 1990. Cloning and nucleotide sequence of a heatstable enterotoxin gene from Vibrio cholerae non$\mathrm{O} 1$ isolated from a patient with traveler's diarrhea. Infect Immun 58: 3325-3329.

Peterson KM, Mekalanos JJ 1988. Characterization of the Vibrio cholerae ToxR regulon: identification of novel genes involved in intestinal colonization. Infect Immun 56: 2822-2829.

Popovic T, Bopp CA, Olsvik Ø, Wachsmuth K 1993. Epidemiologic application of a standardized ribotype scheme for Vibrio cholerae. J Clin Microbiol 31: 2474-2482.

Rhine JA, Taylor RK 1994. TcpA pilin sequences and colonization requirements for $\mathrm{O} 1$ and $\mathrm{O} 139$ Vibrio cholerae. Mol Microbiol 13: 1013-1020.

Salles CA, Momen H 1991. Identification of Vibrio cholerae by enzyme electrophoresis. Trans $R$ Soc Trop Med Hyg 85: 544-547.

Salles CA, Momen H, Vicente ACP, Coelho A 1993. Vibrio cholerae in South America: polymerase chain reaction and zymovar analysis. Trans $R$ Soc Trop Med Hyg 87: 272.

Sambrook J, Fritsch EF, Maniatis T 1989. Molecular Cloning, a Laboratory Manual. 2nd ed. Cold Spring Harbor Lab Press, New York. 
Silhavy TJ, Berman M L, Enquist LW 1984. DNA extraction from bacterial cells, p. 137-139. In Experiments with Gene Fusions, Cold Spring Harbor Lab Press, New York, 303 pp.

Skorupski, K, Taylor RK 1997. Control of the ToxR virulence regulon in Vibrio cholerae by environmental stimuli. Mol Microbiol 25: 1003-1009.

Sperandio V, Bailey C, Girón JA, DiRita VJ, Silveira WD, Vettore AL, Kaper JB 1996. Cloning and characterization of the gene encoding the OmpU outer membrane protein of Vibrio cholerae. Infect Immun 64: 5406-5409.

Sperandio V, Girón JA, Silveira WD, Kaper JB 1995. The OmpU outer membrane protein, a potential adherence factor of Vibrio cholerae. Infect Immun 63: 4433-4438.

Tacket CO, Taylor RK, Losonsky G, Lim Y, Nataro JP,
Kaper JB, Levine MM 1998. Investigation of the roles of toxin- coregulated pili and manose-sensitive hemagglutinin pili in the pathogenesis of Vibrio cholerae O139 infection. Infect Immun 66: 692-695.

Taylor RK, Miller VL, Furlong DB, Mekalanos JJ 1987. Use of phoA gene fusions to identify a pilus colonization factor coordinately regulated with cholera toxin. Proc Natl Acad Sci USA 84: 2833-2837.

Vicente ACP, Coelho A, Salles CA 1997a. Detection of Vibrio cholerae and Vibrio mimicus heat- stable toxin gene sequence by PCR. J Med Microbiol 47: 398402.

Vicente ACP, Novaes RC, Coelho A, Salles CA 1997b. Molecular characterization of TCP cluster in nonO1, non-O139 Vibrio cholerae, p. 243-248. In GT Keusch, M Kawakami (eds), Cytokines, Cholera and the Gut, IOS Press, Netherlands. 
